\title{
GEOLOGIC AND ISOTOPIC MODELS FOR THE CARPATHIAN CRYSTALLINE EVOLUTION
}

\section{IOAN CORIOLAN BALINTONI ${ }^{1}$}

\begin{abstract}
The majority of Carpathian metamorphics protoliths have $\mathrm{T}_{\mathrm{DM}}$ model $\mathrm{Sm} / \mathrm{Nd}$ ages between 1.6 and $2.0 \mathrm{Ga}$. This suggests an important episode of continental crust formation after the $2.0 \mathrm{Ga}$. The Biharia lithogroup (Apuseni Mountains) and the Tulghes lithogroup (East Carpathians) furnished Zircon U/Pb ages from metagranitoids and acid metavolcanics, respective, around $500 \mathrm{Ma}$; this is a sign of existence of some Lower Proterozoic protoliths among Carpathian metamorphics. The bimodal intrusions which are piercing the volcano-sedimentary sequence of Paiuseni lithogroup in Highiş Massif (Apuseni Mountains) have given Permian ages on Zircon $\mathrm{U} / \mathrm{Pb}$ data. The Paiuseni lithogroup probably represents the fill of a rift basin of the same age. The Arieseni, Muntele Mare and Vinta granitoid intrusions from Apuseni Mountains, with $\mathrm{U} / \mathrm{Pb}$ ages between Lower Devonian and Permian, indicates some contractional and extensional processes, in connection with Variscan Orogeny.
\end{abstract}

\section{Introduction}

The last years can be estimated as important for the advance of the Carpathian Crystalline knowledge. Balintoni (1997) proposed a general classification of the Carpathian Metamorphics, depending on the complexity of their metamorphic evolution, the pre-metamorphic tectonic setting of the protoliths, and some meaningful isotopic data. Meanwhile, the isotopic database, and especially the quality of these data have been significantly improved, which makes it possible for us to reconsider these models. The information used proceeds from Pană (1998), Pană et al. (1999), Tatu (1998), Strutinski (1998), Conovici (1999), as well as from some unpublished results. These last data will be only evasively commented on.

\section{The carpathian metamorphics classification}

Excepting the Danubian Metamorphics, Balintoni (1997) classified the Carpathian Metamorphics as follows:

- Proterozoic Metamorphics: the Someş and Baia de Arieş lithogroups in the Apuseni Mountains; Rebra, Negrişoara and Bretila lithogroups in the East Carpathians; Făgăraş and Sebeş-Lotru lithogroups in the South Carpathians;

\footnotetext{
${ }^{1}$ Babeş-Bolyai University, Biology and Geology Faculty, Cluj-Napoca, RO-3400, Romania; E-mail: ibalinto@bioge.ubbcluj.ro
} 
- Caledonian Metamorphics: the Biharia lithogroup in the Apuseni Mountains; Tulgheş in the East Carpathians; the Padeş, Caraş and Miniş sequences in the South Carpathians;

- Variscan Metamorphics: the Păiuşeni lithogroup in the Apuseni Mountains; Rodna in the East Carpathians; the Moniom-Buceava and Hunedoara-Luncani sequences in the South Carpathians.

\section{The significance of some metamorphic isotopic systems}

The metamorphic sequences can be considerate as geological bodies generated at a given moment in the Earth history, and which afterwards evolved under the influence of certain geological factors. Physically, the genesis of a geological body can be conceived as a system individualization, and its evolution as a range of the system changes.

The component parts of the continental crust begin their individual geological history when they separate from the mantle. That moment can be recorded by the $\mathrm{Sm} / \mathrm{Nd}$ isotopic system that, without any new mantle contributions, remains practically inert during its crustal evolution.

Within the continental crust, the first order system changes, associated to the magmatic remobilizations, are highlighted by the Zircon $\mathrm{U} / \mathrm{Pb}$ isotopic systems. For these studies the most suitable rocks are the granitoids and acid volcanic suites. The $\mathrm{U} / \mathrm{Pb}$ isotopic systems can provide either pre-metamorphic crustal protolith ages or metamorphic event ages, if accompanied by magmatism.

The thermal changes of the system, attended or not by the neomineralizations and/or magmatism, can be revealed by the $\mathrm{Ar} / \mathrm{Ar}$ and $\mathrm{K} / \mathrm{Ar}$ isotopic systems. The concrete significance of all isotopic-age types can be appreciated only if one knows their geological context.

\section{The Sm/Nd ages}

Pană (1998) and Pană et al. (1999) presented several dozen of $T_{\mathrm{DM}}$ model Sm/Nd ages for protoliths from Someş, Biharia, Baia de Arieş and Păiuşeni lithogroups of the Apuseni Mountains, the Bretila, Rebra, Tulgheş and Negrişoara lithogroups of the East Carpathians, and the Sebeş-Lotru and Făgăraş lithogroups of the South Carpathians. The 1.61-2.07 Ga interval for age's range suggests the idea that the constitutive material of the Carpathian Metamorphics separated from the mantle during this period. The sequences classified as Caledonian or Variscan probably indicate basinal or magmatic recycling of some pre-existing materials. In accordance with Condie's data (1989), the 1.6-2.0 Ga interval and especially the one between 1.7-1.9 Ga, was characterized in North-America and Europe by an accelerated continental crust extraction from the mantle. Myiashiro (in Myiashiro et al, 1982) notes the Karelian orogeny in the Baltic shield, and the Hudsonian one in North America, as major thermotectonic events during 
that period. For the Carpathian Metamorphic piles, classified as Proterozoic by Balintoni (1997), for the time being, we have not obtained the U/Pb ages to confirm this time interval as a system change period. In the absence of the $\mathrm{U} / \mathrm{Pb}$ ages, the $\mathrm{Sm} / \mathrm{Nd}$ data can be also interpreted as mixtures between protoliths older than $2.0 \mathrm{Ga}$ and other younger.

\section{The zircon U/Pb ages and fossil ages}

Pană (1998) provided a set of zircon U/Pb ages from many of the Apuseni Mountains granitoids.

For the Someş lithogroup protoliths, relevance can be attributed, to a certain extent, to the $372 \mathrm{Ma}$ and the $392 \mathrm{Ma}$ ages, obtained from the granites, called by Pană (1998) the Codru and Mădrizeşti granitoids (the Arieş granitoids in Balintoni, 1997), which point to the fact that the Someş protoliths are older than the respective granitoids.

On the other hand, the ages around $500 \mathrm{Ma}$ obtained for the granitoids called the Lunca Largă granitoids (Balintoni, 1997), which alternate pseudo-stratigraphically with the Biharia lithogroup metabasites, point to the presence of Caledonian protoliths, possibly younger than the green rocks.

It is difficult to say when the Biharia lithogroup was for the first time metamorphosed. But, because the Biharia lithogroup constitutes the Păiuşeni lithogroup basement of Permian age (Pană, 1998), surely the initial regional metamorphism of the Biharia lithogroup might be accomplished before the Permian or Upper Carboniferous times.

The U/Pb ages of the acid metavolcanics from the East Carpathians Tulgheş lithogroup are very close to those of the Lunca Largă granitoids. Consequently, the Biharia and the Tulgheş lithogroups reveal Caledonian basinal and magmatic recycling of some pre-existing crustal materials, essentially in agreement with the genetic model proposed for them by Balintoni (1997).

In the case of the Păiuşeni lithogroup, Pană (1998) obtained for the two members of the Highiş bimodal magmatic complex (Tatu, 1998), 267 Ma and $264 \mathrm{Ma}$ ages respectively. As a result, the volcano-sedimentary sequence of the Păiuşeni lithogroup, which was pierced and thermally metamorphosed by the Highiş intrusions, has Permian or a little older age, but at any way, younger than the metamorphics of the Biharia lithogroup, which are shuffled in the Păiuşeni lithogroup formations.

Conovici (1999) described an Ordovician fauna from the Buceava sequence of the South Banat. This sequence, partially terrigenous and partially volcanic (basaltoid), is metamorphosed in a very low degree and is supported by the Sebeş-Lotru crystalline.

As a conclusion of this section, we retain that the metamorphic sequences which have been individualized before the Permian have been dated in all the three Carpathian branches, because all of them support sedimentary 
deposits beginning with the Upper Carboniferous (Buceava), Lower Permian (Biharia) or Triassic (Tulgheş) (Săndulescu, 1984; Balintoni, 1997). The Padeş suite from the Poiana Ruscă Massif is lithostratigraphically comparable with the Tulgheş lithogroup, and we admit the same age for both of them.

\section{KIAr and ArIAr ages}

Dallmeyer et al. (1994) and Pană (1998) reported Ar/Ar ages from the South Carpathians and the Apuseni Mountains, respectively. Based upon the data provided by the papers published since 1964, Strutinski (1998) realized a synthesis of the $\mathrm{Ar} / \mathrm{Ar}$ and K/Ar mineral ages. For the present text it is important that the majority of these ages are grouped in a time interval corresponding to the Variscan Orogeny, that is between Permian and Devonian, with a marked concentration during Carboniferous.

The intensity of the Variscan thermo-tectonic processes over the entire Carpathian territory, except the Danubian domain, was one of the reasons for which its pre-Variscan evolution has been insufficiently known and misunderstood for a long time. On the other hand, a number of the Romanian metamorphicists knew that the true Variscan metamorphics had but little importance in the constitution of the Carpathian terrains. Because the isotopic data from the systems with a great inertia are insufficient, this dilemma still persists. The Paleozoic Wilson Cycle being conventionally divided into the Caledonian and Variscan orogenies, the relationship between these represents another problem.

\section{Discussion}

The above presented data enable us to do several inferences about the Carpathian Crystalline evolution.

The first of them is that the material of the Carpathian metamorphics could be younger than $2.0 \mathrm{Ga}$, majority of the $\mathrm{Sm} / \mathrm{Nd}$ ages ranging between $1.6 \mathrm{Ga}$ and $2.0 \mathrm{Ga}$. Naturally, without controlling $\mathrm{Sm} / \mathrm{Nd}$ ages with $\mathrm{U} / \mathrm{Pb}$ data, the hypothesis of a mixture between materials older than $2.0 \mathrm{Ga}$ and those much younger than this age, cannot be ruled out.

The second inference is that some metamorphic sequences contain Lower Paleozoic protoliths. For the time being, this is the case of the Biharia lithogroup from the Apuseni Mountains, the Tulgheş lithogroup from the East Carpathians, the Buceava sequence from South Banat and probably the Padeş sequence from the Poiana Ruscă Massif. With the exception of the Padeş sequence which parallels with the Tulgheş lithogroup, each of the other three successions appears to have its own geological history.

The Biharia lithogroup was metamorphosed before the Carboniferous time, because it underlay the Păiuşeni lithogroup which recorded Carboniferous and Permian thermo-tectonic influences (Pană, 1998). The characteristic rockassociation is formed by basic and acid metavolcanics, which appear to be 
together regionally metamorphosed, and mutually equilibrated in the greenschists facies. We opine that the Biharia lithogroup is evidence of Paleozoic suture which separated the two older continental crusts: the Someş lithogroup situated in at present in the north, and the Baia de Arieş lithogroup situated in the south of the area covered now by the Biharia lithogroup. These two continental crusts were evolving apart since at least the end of Cambrian, and it is possible that the Arieş granitoids (Balintoni, 1997), for which Pană (1998) obtained Devonian U/Pb ages, to indicate the time when the intervening basin between these crusts closed. A hypothesis concerning the Biharia lithogroup origin is that it formed a Proterozoic island arc intruded by the Upper Cambrian-Lower Ordovician granitoids, remobilized from its root part, as a sign of the subduction resumption beneath it. The metamorphism of the basic metavolcanics and granitoids could be of Devonian age, contemporary with the Arieş granitoids genesis that intruded the margin of the Someş continental crust fragment.

In this hypothesis, within the Biharia lithogroup there are "Caledonian" protoliths, but no metamorphics, the latter belonging to the Early Variscan Orogeny.

The Tulgheş lithogroup represents a terrigenous and acid metavolcanic association. It also contains Lower Proterozoic protoliths, and its genetic context appears to be of an island arc too, evolving towards a back-arc basin. According to the metamorphic history of its rocks, more complex that the one of the Biharia lithogroup, one can suppose that the Tulghes lithogroup was metamorphosed at the end of Ordovician, in a contractional setting too.

An interesting observation refers to the fact that, like the Biharia lithogroup, the Tulgheş lithogroup was also situated between two different continental crusts: the Bretila lithogroup similar to the Someş lithogroup as far as its pre-metamorphic origin is concerned, and Rebra lithogroup comparable to the Baia de Arieş lithogroup. We can go further with the conjectures and suppose that during the Cambrian, the Someş and Bretila lithogroups built together a common continental fragment, while Rebra and Baia de Arieş did another one; between them there intervened the same ocean, with different tectonic settings along it. Without being in relation with an Upper Paleozoic sequence, as the Biharia lithogroup was, the Tulghes lithogroup furnished several KJAr Carboniferous ages, which are signs for its involvement in the Variscan thermo-tectonic event. In conclusion, during the Lower Paleozoic the Biharia and Tulgheş lithogroups began their history as independent entities, but it is not clear if they supported the first thermotectonic processing at the end of the Caledonian Orogeny or at the beginning of the Variscan one. 
If we understand the Caledonian Orogeny as generating metamorphics during the Upper Cambrian-Silurian interval, then in the Apuseni Mountains and East Carpathians this orogeny is probably not represented. In other words, during the Lower Paleozoic, the Bretila and Someş lithogroups on the one hand, and the Rebra and Baia de Arieş lithogroups on the other hand, were evolving together as independent continental fragments; they juxtaposed only when the Biharia and Tulgheş lithogroups became metamorphics from volcano-sedimentary associations.

We cannot say if the two continental fragments separated by rifting at the Paleozoic beginning or they joined for the first time when the oceanic space between them was eliminated.

The Buceava sequence indicates a rift and a Paleozoic subduction within the Sebeş-Lotru lithogroup, because the rift closing can be associated with the linear Sichevița-Poniasca granitoid, Upper Paleozoic in age (Conovici, 1999). So, the Buceava sequence suggests a Caledonian rifting and a Variscan suture, or a continuity of the two orogenies.

The Păiuşeni lithogroup appears to be quite interesting for the End Paleozoic history of the Apuseni Mountains. Tatu's study (1998) showed that the basic and acid magmatic rocks from the Highiş Massif represent synchronous terms of a bimodal magmatism emplaced in an extensional tectonic setting. For both terms, Pană (1998) obtained Permian U/Pb data. The intrusions pierced and thermally metamorphosed a consanguine, volcanosedimentary suite. Because some $\mathrm{Ar} / \mathrm{Ar}$ data obtained from the Biharia lithogroup rocks and the matrix of the Păiuşeni lithogroup conglomerates are Carboniferous, one can admit that the sedimentation of the Păiuşeni lithogroup began during the Carboniferous, when all the metamorphosed lithogroups from the Apuseni Mountains passed from mid-crustal levels to upper ones.

Besides the Highiş bimodal magmatic rocks, the Muntele Mare and Vința granitoids (295 Ma and 261 Ma respectively; Pană, 1998) should also be considered as extensional ones. Both of them are localized as two isolated bodies, in the proximity of Biharia lithogroup, which underlie the Păiuşeni lithogroup rift-type sequences.

As a conclusion, the Păiuşeni lithogroup is the direct proof of the generalized extensional period that immediately followed the Variscan contractional climax: this extension was responsible for the entire Permian magmatism of the Carpathian area. The bimodal character of the Permian magmatism can be observed in other structural units of the Apuseni Mountains too, not only in the Highiş Massif. It is possible that the Păiuşeni lithogroup was metamorphosed just during the Alpine Orogeny, when the Biharia Nappe System was also emplaced. 


\section{Conclusions}

(1) The mutual relationships between the Biharia lithogroup and Someş and Baia de Arieş lithogroups in the Apuseni Mountains, between the Tulgheş lithogroup and Bretila, Rebra and Negrişoara lithogroups in the East Carpathians and between the Buceava sequence and the Sebeş-Lotru lithogroup in the South Carpathians, strongly suggest a Proterozoic age for the Someş, Baia de Arieş, Bretila, Rebra, Negrişoara, Sebeş-Lotru and Făgăraş lithogroups metamorphics.

(2) The apparent $\mathrm{Sm} / \mathrm{Nd} \mathrm{T}_{\mathrm{DM}}$ model age of the metamorphic Carpathian protoliths does not exceed $2.0 \mathrm{Ga}$. This is an important contribution of the last years for the Carpathian geology.

(3) The existence of Lower Paleozoic protoliths within the Biharia, Tulgheş and Buceava sequences is confirmed. Especially in the case of Biharia and Tulgheş lithogroups, these protoliths were regionally metamorphosed during the Early Variscan Orogeny.

(4) The Carboniferous Ar/Ar and K/Ar ages indicate a generalized exhumation of Carpathian terraines in that period. If initially this exhumation might be put in relation with the ending of the Paleozoic convergences, the ultimate ones were followed by a general extension, beginning with the Uppermost Carboniferous End and continuing during the Permian.

(5) One of the Permian rifts accompanied by bimodal extrusive and intrusive magmatism is quite well expressed in the Apuseni Mountains. The basinal fill is represented by the Păiuşeni lithogroup.

(6) The Vința and Muntele Mare granitoids were also generated in connection with the extensional tectonic setting localized along the area covered by the Biharia lithogroup during the Permian.

(7) The Păiuşeni lithogroup rocks probably were metamorphosed just during the Alpine Orogeny.

(8) The Someş, Bretila and Sebeş-Lotru lithogroups on the one hand and the Baia de Arieş, Rebra, Negrişoara and Făgăraş on the other hand, were probably forming at the beginning of Paleozoic two different continental fragments, separated by an oceanic branch. The Biharia and Tulgheş lithogroups were generated in connection with the convergence processes from this oceanic branch.

(9) One cannot say if the oceanic branch from which the Buceava Sequence proceeded was or not in connection with the one from which were issued the Biharia and Tulgheş lithogroups.

(10) The discussed Lower Paleozoic rifts were situated out of the Caledonian suture which welded the Central and Western Europe to the East-European Platform (the Tornquist-Teysseire line).

(11) It is clear that the protolith and metamorphic ages have different meanings. These notions were not clearly discerned until present in the Romanian geological literature. 
(12) The distinction between the Caledonian and Variscan Orogenies is but conventional. The Upper Proterozoic or Lower Paleozoic rifts closed gradually during the Paleozoic.

(13) Some Proterozoic sequences appear to be generated in different places; it seems that they welded during the Paleozoic.

(14) The Paleozoic granitoids from the Apuseni Mountains suggest contractional or convergent tectonic settings as some extensional or divergent.

Acknoledgments. This article was funded by the Grant 16/1997 (World Bank), provided by National Education Ministry of Romania. We are also indebted to Dinu Pană (Edmonton) for the manuscript review.

\section{REFERENCES}

1. B a I i n t o n i, I., (1997), Geotectonica terenurilor metamorfice din România. Ed. Carpatica, 176 p., Cluj-Napoca.

2. C o n d i e, C. K., (1989), Plate Tectonics and Crustal Evolution. Pergamon Press, New York, 288p.

3. Condi e, C. K., (ed.) (1994), Archaean Crustal Evolution. Elsevier, 527p.

4. C o n o vi c i, M., (1999), Studiul Geostructural al domeniului getic-supragetic din sud-vestul Carpaților meridionali. Teză de doctorat, Universitatea Babeş-Bolyai, Cluj Napoca.

5. D a I I $\mathrm{m}$ e y e r, R. D., N e u b a u e r, F., P a n ă, D., F r i t z, H., (1994), Variscan vs. Alpine Tecthonotermal Evolution Within the Apuseni Mountains, Romania: Evidence from $\mathrm{Ar}^{40} / \mathrm{Ar}^{39}$ Mineral Ages, ALCAPA II, Field Guide-Book, Rom. Jour. Tect. Reg. Geol., 75. Suppl. 2, 65 - 76, Bucureşti.

6. I a n c u, V., B a I i n t o n i, I., S ă b ă u, G., (1988), Variscan Tectonic Units from the Getic Domain, Bozovici Zone, D. S. Inst. Geol. Geofiz. 72-73/5, 153-161, Bucureşti

7. P a n ă, D., (1998), Petrogenesis and Tectonics of the Basement Rocks of the Apuseni Mountains: Significance for the Alpine Tectonics of the CarpatianPannonian Region. Ph.D. Thesis, Univ of Alberta, Canada.

8. P a n ă, D., B a I i n t o n i, I., C r e a s e r, R., (1999), Sm/Nd Data from Basement Rocks of the Romanian Carpathians. $31^{\text {st }}$ I.G.C. 2000, Rio de Janeiro

9. M i y a s h i r o, A., A k i, K., S e n g o r, A. M. C., (1982), Orogeny. Ed. J. Willey, New York.

10. S ă n d u I e s c u, M., (1984), Geotectonica României, Ed. Tehn., Bucureşti, $336 \mathrm{p}$.

11. S t r u t i n s k i, C., (1998), Metamorfismul alpin al seriilor cristaline precambriene din Carpați. Arh. I.G.R., Bucureşti.

12. T a t u, M., (1998), Le Massif Highiş (Roumanie) un exemple de l'evolution du magmatisme alcalin anorogenique. These, Universite de Paris-Sud, centre d'Orsay. 